\title{
Isotopic evidence of particle size-dependent food partitioning in cocultured sea squirt Halocynthia roretzi and Pacific oyster Crassostrea gigas
}

\author{
Chang-Keun Kang ${ }^{1, *}$, Eun Jung Choy $^{2}$, Young-Baik Hur ${ }^{3}$, Jeong-In Myeong ${ }^{2}$ \\ ${ }^{1}$ Department of Biology, Pusan Nation University, Busan 609-735, Korea \\ ${ }^{2}$ Polar Research Institute, Korea Ocean Research and Development Institute (KORDI), Incheon 406-840, Korea \\ ${ }^{3}$ Aquaculture Environment Research Center, National Fisheries Research and Development Institute, Kyeongnam 650-943, Korea
}

\begin{abstract}
To examine the trophic relationship between the sea squirt Halocynthia roretzi and the Pacific oyster Crassostrea gigas cocultured in suspension, their $\delta^{13} \mathrm{C}$ and $\delta^{15} \mathrm{~N}$ values were monitored monthly on the southern coast of Korea for a period of $2 \mathrm{yr}$. Suspended particulate organic matter was fractionated as coarse $(>20 \mu \mathrm{m}, \mathrm{CPOM})$ and fine particles $(<20 \mu \mathrm{m}, \mathrm{FPOM})$, and the seasonal variations in the $\delta^{13} \mathrm{C}$ and $\delta^{15} \mathrm{~N}$ were determined. CPOM $\delta^{13} \mathrm{C}$ was slightly more variable than FPOM $\delta^{13} \mathrm{C}$ over the sampling period, whereas $\delta^{15} \mathrm{~N}$ varied less for CPOM than for FPOM. Co- and monocultured sea squirts had a less variable $\delta^{13} \mathrm{C}$, but a more variable $\delta^{15} \mathrm{~N}$ than cocultured oysters over the sampling period. The $\delta^{13} \mathrm{C}$ and $\delta^{15} \mathrm{~N}$ of cocultured sea squirts were consistently lower than those of cocultured oysters. The more pronounced difference in the $\delta^{13} \mathrm{C}$ between the cocultured suspension feeders was attributed to a striking isotopic change in oysters during their autumn to winter growing period. Differences in the $\delta^{13} \mathrm{C}$ were significant between co-, monocultured, and wild sea squirts, but not between co- and monocultured oysters. These suspension feeders can use different POM size fractions within the same habitat. The marked ${ }^{13} \mathrm{C}$-enrichment in oyster tissues, particularly during their fast growing period, may result from their strong selectivity of diatoms. In contrast, both the ${ }^{13} \mathrm{C}-$ and ${ }^{15} \mathrm{~N}$-depleted values in cocultured sea squirts indicate the importance of pico-/nano-size fractions as their dietary components. Size-related patterns in food resource exploitation between the cocultured suspension feeders may be due to different particle capture mechanisms.
\end{abstract}

KEY WORDS: Halocynthia roretzi - Crassostrea gigas · Coculture - Stable isotopes - Trophic relationship · Food partitioning

\section{INTRODUCTION}

Aquaculture of suspension-feeding bivalves and other invertebrates is an area of tremendous economic potential in coastal waters worldwide. It is believed that populations cultured in suspension using a long, constantly submerged line system have the benefits of fast growth and high production over their wild counterparts (Rodhouse et al. 1984, Garen et al. 2004). Great attention has been paid to the ecological impacts of suspension-feeding communities on the quantity and quality of phytoplankton populations (Baker et al. 1998, Souchu et al. 2001). The grazing activity of cultivated animals may enhance nutrient recycling and increase light in the water column so that algal growth is stimulated and, in turn, food quality is improved by this positive feedback (Asmus \& Asmus 1991, Prins et al. 1997). Alternatively, high stock densities of wild or cultivated suspension feeders may deplete phytoplankton biomass and suspended particulate matter in the water column (Cloern 1982, Jarry et al. 1990, Souchu et al. 2001). Such a negative feedback may result in lower growth rates in the cultivated stocks (Prins et al. 1998 and references therein).

The 2 most important aquaculture species in Korea are the edible sea squirt Halocynthia roretzi and the Pacific oyster Crassostrea gigas. The longline method for sea squirt production was expanded in 1980 and 
peaked at 42800 tons in 1994 , declining to 4500 tons in 2004 and 10819 tons in 2006 (National Fisheries Research and Development Institute 2004). The decline in sea squirt production is attributed to a decrease in growth rate and an increase in mass mortality events. Causes of ubiquitous mass mortalities of sea squirts on Korean coasts are still unknown. Recently, fishermen developed a coculturing method, in which one line has sea squirts attached, and the next parallel line has oysters attached. With the expansion of this method, the mortality of $H$. roretzi was less pronounced. In contrast, during that time, mass mortalities happened much more frequently under an ascidian monoculture. In relation to the availability of food and the density of cultivated or wild populations, increasing the stocking density of cultured bivalves above the optimal level for a given site often leads to a significant reduction in growth and survivorship of the cultured stocks (Newell 1990, Parsons \& Dadwell 1992, Raillard \& Ménesguen 1994). Similarly, the declining growth rate and high mortality under ascidian monoculture conditions may be associated with the stocking density exceeding the trophic capacity of the system. In contrast, the reduced mortality under cocultures of ascidians and oysters may be indicative of a mitigation of food limitation. This may result from an insignificant competitive interaction for food resources between those 2 suspension-feeder stocks.

Several ascidian species co-occurring on the longline culture units of bivalves were considered to be fouling organisms or potential competitors with cultivated bivalves for food resources (Cayer et al. 1999, Carver et al. 2003). However, various laboratory feeding experiments have demonstrated that the co-occurring suspension-feeding ascidians and bivalves possess different mechanisms for particle capture (Stuart \& Klump 1984, Lesser et al. 1992, Petersen 2007). Resource partitioning due to species-specific differences in qualitative selection capability in co-occurring mollusk communities was also found between an indiscriminate suspension-feeding gastropod Crepidula fornicate and a selectively feeding oyster Crassostrea gigas (Riera et al. 2002, Decottignies et al. 2007). In the same manner, as ascidians lack a particle sorting mechanism (Petersen 2007), partitioning food resources due to differences in particle selection capability between cocultured sea squirts and oysters may be expected.
The present study was carried out to elucidate the trophic interactions of sea squirts Halocynthia roretzi and Pacific oysters Crassostrea gigas cocultured in suspension using longlines. The $\delta^{13} \mathrm{C}$ and $\delta^{15} \mathrm{~N}$ values of these 2 suspension feeders were monitored monthly and compared with those of suspended particulate organic matter (POM) as potential food sources. By comparing the $\delta^{13} \mathrm{C}$ and $\delta^{15} \mathrm{~N}$ values of the suspension feeders with those of size-fractioned POM, we examined seasonal variations in the suspension feeders' food sources based on particle size ingested to provide evidence for food-resource partitioning.

\section{MATERIALS AND METHODS}

Field sites and sampling design. Our sampling occurred at 4 sites on the mid-south coast of Korea (Fig. 1). Cultivation of a variety of suspension feeders, including sea squirts (Halocynthia roretzi and Styela clava), oysters (Crassostrea gigas), and mussels (Mytilus galloprovincialis) is widely exploited in this area using ropes suspended from longlines. Over $90 \%$ of Korea's oyster and sea squirt production comes from intensive longline cultures in this area (http://fs.fips.go.kr/index. jsp). Sea squirts and oysters were collected monthly at 4 sites from February 2005 to December 2006. Cocultured sea squirts and oysters came from Site C (Goseong), monocultured sea squirts from Site $\mathrm{S}$ (Youngun), monocultured oysters from Site O (Youngun), and a wild population of sea squirts came from Site D (Dae-

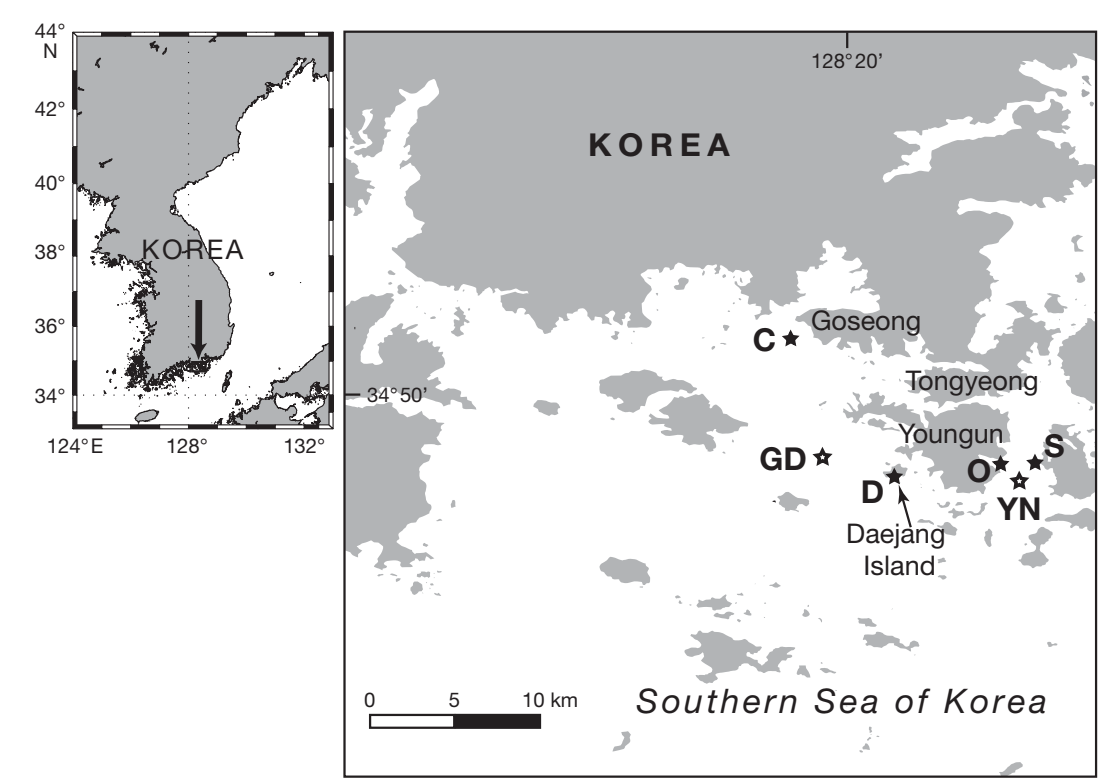

Fig. 1. Location of sampling sites on the mid-south coast of Korea. Site C: cocultured sea squirts and oysters; Site S: monocultured sea squirts; Site O: monocultured oysters; Site D: a natural population of sea squirts; Sites GD and YN: sites for suspended particulate organic matter sampling 
jang). These sites were selected to take samples representative of different types of culture systems, e.g. mono- or coculture systems of oysters and sea squirts. Detailed information on the distribution, general ecology and habitat, seed collection, and cultivation processes of oysters and sea squirts in this area have been reported elsewhere (National Fisheries Research and Development Institute 2004).

The sampling sites in this study had a depth of $<20 \mathrm{~m}$. The tidal cycle of this area is semidiurnal, with maximal tidal amplitude of $\sim 2.0 \mathrm{~m}$ on spring tides. Main currents are dominated by south- and northward reversing tidal current ( 10 to $20 \mathrm{~cm} \mathrm{~s}^{-1}$ near the sea surface) during the ebb and flood tides. The water temperatures showed a clear seasonal cycle typical of a temperate zone, with a summer maximum around $26.7^{\circ} \mathrm{C}$ in September and a winter minimum around $5.4^{\circ} \mathrm{C}$ in February. Salinities are lower during the summer monsoon period (around 28) and higher in the winter to spring dry season (around 34). These sites are free of large-scale river runoff. However, concentrated rainfall brings high nutrient concentrations during late spring to early summer, accompanied by high concentrations of chlorophyll a ( $\mathrm{chl} \mathrm{a}$ ), indicating the summer phytoplankton bloom.

Sample collection and processing. The sea squirt and oyster larva collectors were moved to the nursery ground. Several months later, the collectors were taken to the farm and attached as vertical ropes hung from the longline (detailed procedures are in National Fisheries Research and Development Institute 2004). About 50 ind. of both species were randomly collected by hand from depths of 1 to $5 \mathrm{~m}$ at each site. Specimens were transported to the laboratory and cleaned to remove any attached epifauna. They were then acclimated overnight in filtered seawater at the in situ temperature to ensure gut evacuation and removal of fecal contents. After rinsing, the length, width, and height of the oyster shell and the sea squirt tunic were measured to the nearest $0.1 \mathrm{~mm}$ using vernier calipers. The animals were then dissected carefully, and their tissues were frozen and stored at $-20^{\circ} \mathrm{C}$. The shell valves and tunics were rinsed with distilled water and weighed $72 \mathrm{~h}$ after being placed in a drying oven at $50^{\circ} \mathrm{C}$. The dry tissue weights of both species were determined after freeze-drying for a period of $72 \mathrm{~h}$. A condition index was calculated from the dry tissue weight and tunic (for tunicates) or shell volume (for oysters) according to the formula: condition $=$ (dry tissue weight $/$ total dry weight or shell weight) $\times 100$ (Petersen et al. 1997). Then, the dried tissues of 10 ind. from each site were pooled and mill ground into a homogeneous powder for isotope analysis.

Potential sources of organic matter available to cultivated invertebrates in the study area (i.e. particulate matter suspended in the water column [seston]) were sampled from duplicate samples in a volume of about 601 of subsurface water (at a depth of about $1 \mathrm{~m}$ below the water surface) at 2 sites (Site GD for cocultured and wild sea squirt sites, and Site YN for monoculture sites, Fig. 1) using a van Dorn water sampler. Water samples were collected at these sites at midday high tide during spring tide periods to rule out waters filtered by intensively cultured organisms north of the sites during the ebb tides. The water samples were immediately passed through a $180 \mu \mathrm{m}$ Nitex mesh to eliminate zooplankton and large particles, and collected in acid-washed plastic bottles. Water from these samples was then passed through a $20 \mu \mathrm{m}$ sieve to obtain coarse suspended particulate organic matter (CPOM) comprised of mainly micro-sized phytoplankton. The remaining water was filtered once again through precombusted Whatman GF/F glass-fiber filters (nominal pore size $=0.7 \mu \mathrm{m}$ ) to obtain fine suspended particulate organic matter (FPOM) representing pico- and nano-plankton. Additional separation of seston was not attempted because of the difficulty in acquiring a sufficient sample for isotopic analysis. The sieved and filtered particulates for organic carbon isotope analysis were treated with 2 to 3 drops of $1 \mathrm{~N}$ $\mathrm{HCl}$ to remove any inorganic carbonate. Because acid washing can affect the nitrogen isotope ratios of organic material (Bunn et al. 1995), samples for nitrogen isotope analysis were not acidified. Invertebrate tissues were not acid washed before stable isotope analysis.

Stable isotope analysis. Stable carbon and nitrogen isotope assays were performed on small quantities of subsamples from homogenized materials. One milligram of powdered subsample was loaded into tin combustion cups and combusted at high temperature $\left(1030^{\circ} \mathrm{C}\right.$ ) in an automated elemental analyzer (Euro EA 3000). The resulting $\mathrm{CO}_{2}$ and $\mathrm{N}_{2}$ gases were then analyzed using an interfaced continuous flow isotope ratio mass spectrometer (CF-IRMS, GV Isoprime). Two laboratory standards were analyzed with every tenth unknown sample. Stable isotope abundances were expressed in conventional delta $(\delta)$ notation, as deviation in parts per thousand (\%) relative to the Pee Dee Belemnite and atmospheric $\mathrm{N}_{2}$ standards for carbon and nitrogen, respectively. The ratios were derived from the equation: $\delta X(\%)=\left[\left(R_{\text {sample }} / R_{\text {standard }}\right)-1\right] \times 10^{3}$, where $X$ is ${ }^{13} \mathrm{C}$ or ${ }^{15} \mathrm{~N}$, and $R$ is the corresponding ratio of ${ }^{13} \mathrm{C} /{ }^{12} \mathrm{C}$ or ${ }^{15} \mathrm{~N} /{ }^{14} \mathrm{~N}$. International Atomic Energy Agency (IAEA) CH-6 (sucrose, $\delta^{13} \mathrm{C}=-10.45 \pm 0.07 \%$ ) and IAEA-N1 (ammonium sulfate, $\delta^{15} \mathrm{~N}=0.4 \pm 0.2 \%$ ) with a known relationship to the international standard were used as reference materials. The SD of repeated measurements of internal peptone and urea standards was $<0.2 \%$ for $\delta^{13} \mathrm{C}$ and $<0.3 \%$ for $\delta^{15} \mathrm{~N}$. 
Statistical analysis. Data were tested for normality using the Shapiro-Wilk test and for homogeneity of variance using Leven's test to meet the assumption of parametric statistics. Three-way analysis of variance (ANOVA) was used to test statistically significant differences in the $\delta^{13} \mathrm{C}$ and $\delta^{15} \mathrm{~N}$ values (dependent variables) of the POM due to the sampling site, POM type (size classes of CPOM and FPOM), and sampling month as factors. Because of significant interactions in the $\delta^{13} \mathrm{C}$ and $\delta^{15} \mathrm{~N}$ values of the POM between the POM type and the sampling month, a Student's $t$-test was used to test isotopic differences between the CPOM and FPOM for pooled data from 2 sampling sites for each sampling occasion. One-way ANOVA and the Tukey test for multiple comparisons were used to test temporal differences in carbon and nitrogen isotopic values. Then, similarities in the seasonal variation of the $\delta^{13} \mathrm{C}$ and $\delta^{15} \mathrm{~N}$ values between the culture types of the animals were compared using Spearman's rank correlation coefficient. A paired $t$-test was used to examine differences in the mean isotope values of animals between animal groups. All tests were performed using the SPSS 12.0 statistical software package.

\section{RESULTS}

\section{$\delta^{13} \mathrm{C}$ and $\delta^{15} \mathrm{~N}$ values of the suspended particulate organic matter}

Results from the 3-way ANOVA tests showed that there was no significant difference in the $\delta^{13} \mathrm{C}$ and $\delta^{15} \mathrm{~N}$ values of the POM between the GD and YN sites ( $p=0.387$ and 0.251 for $\delta^{13} \mathrm{C}$ and $\delta^{15} \mathrm{~N}$, respectively; Table 1). In contrast, significant differences in both the $\delta^{13} \mathrm{C}$ and the $\delta^{15} \mathrm{~N}$ values were found between the size classes of the CPOM and FPOM $(p<0.001)$. There was no significant interaction in the $\delta^{13} \mathrm{C}$ and $\delta^{15} \mathrm{~N}$ values between the sampling site and the POM size class $(p=0.148$ and 0.864 , respectively), indicating consistent differences in the $\delta^{13} \mathrm{C}$ and $\delta^{15} \mathrm{~N}$ values between the CPOM and FPOM at both sites. While there were significant differences in the $\delta^{13} \mathrm{C}$ and $\delta^{15} \mathrm{~N}$ values in the POM between months ( $<<0.001)$, interactions between the sampling site and the sampling month were not significant $(p=0.932$ and 0.998 , respectively). On the other hand, strong statistical interactions in the $\delta^{13} \mathrm{C}$ and $\delta^{15} \mathrm{~N}$ values in the POM between the POM type and the sampling month occurred ( $\mathrm{p}<0.001$ for both the $\delta^{13} \mathrm{C}$ and $\delta^{15} \mathrm{~N}$ values) These interactions revealed that the temporal variability in the $\delta^{13} \mathrm{C}$ and $\delta^{15} \mathrm{~N}$ values was inconsistent between the CPOM and FPOM, i.e. the temporal variability in the values did not parallel the size classes. However, the insignificant interactions in the $\delta^{13} \mathrm{C}$ and $\delta^{15} \mathrm{~N}$ values among the 3 factors (site $\times$ type $\times$ month) indicated that the temporal variability in the $\delta^{13} \mathrm{C}$ and $\delta^{15} \mathrm{~N}$ values, depending on the types of POM, was common to both sites.

The $\delta^{13} \mathrm{C}$ and $\delta^{15} \mathrm{~N}$ values of all size classes of the POM ranged from -23.7 to $-15.4 \%$ and from 3.3 to $9.7 \%$, respectively, at Sites GD and YN (Fig. 2). The $\delta^{13} \mathrm{C}$ values of the CPOM were slightly more variable, with a range of -21.9 to $-15.4 \%$ (coefficient of variations $[\mathrm{CVs}]=8.5$ and 8.8 at Sites GD and $\mathrm{YN}$, respectively), than those of the FPOM, with a range of -23.6 to $-19.7 \%$ ( $\mathrm{CVs}=4.4$ and 3.8 , respectively) over the sampling period. In contrast, the $\delta^{15} \mathrm{~N}$ values of the CPOM were less variable, with a range of 6.2 to $9.7 \%$ (CVs $=9.2$ and 10.5 at Sites GD and YN, respectively), than those of the FPOM, with a range of 3.3 to $8.6 \%$ (CVs $=20.2$ and 19.2, respectively). As a result, while greatly elevated $\delta^{13} \mathrm{C}$ values in the CPOM were found in the summer of 2005 and in summer to early fall of 2006 , the $\delta^{15} \mathrm{~N}$ values in the FPOM peaked in the summer to early fall of 2005 (Tukey HSD test, p < 0.05). Although the unparalleled temporal variability in the $\delta^{13} \mathrm{C}$ and $\delta^{15} \mathrm{~N}$ values between the CPOM and FPOM resulted in quite variable differences between the size classes, the FPOM was consistently depleted in ${ }^{13} \mathrm{C}$ and ${ }^{15} \mathrm{~N}$ relative to the CPOM on each sampling occasion (Student's $t$-test, $\mathrm{df}=6, \mathrm{p}<0.05$ for $\delta^{13} \mathrm{C}$ on all the 23 sampling occasions and for $\delta^{15} \mathrm{~N}$ on 22 occasions except for $\mathrm{p}=0.668$ in October 2005). The monthly differences between the 2 size fractions of the POM averaged $2.8 \pm 1.1 \%$ o (1 SD) and $2.1 \pm 0.9 \%$ in the $\delta^{13} \mathrm{C}$ and $\delta^{15} \mathrm{~N}$ values, respectively. 

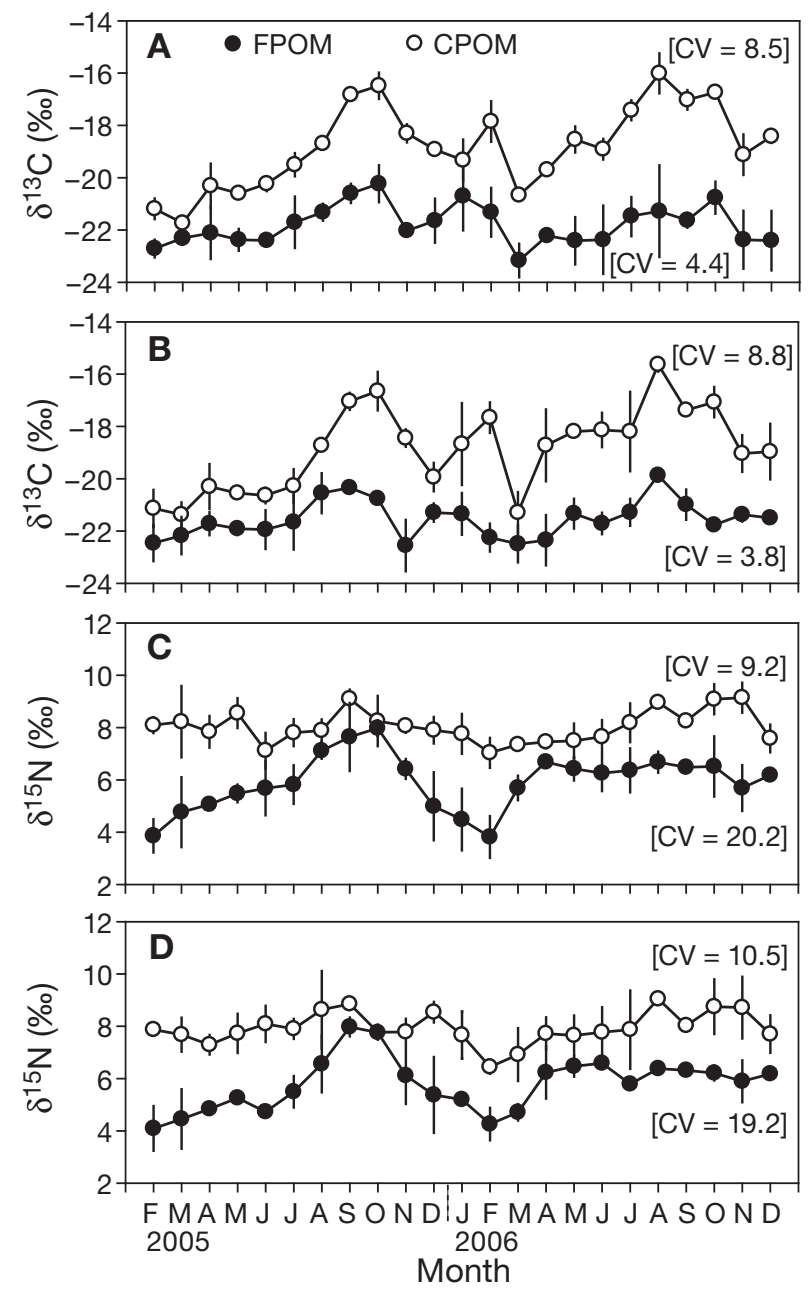

Fig. 2. Monthly means ( $\pm 1 \mathrm{SD}$ ) of $\delta^{13} \mathrm{C}$ and $\delta^{15} \mathrm{~N}$ values of suspended particulate organic matter (POM) at the GD $(\mathrm{A}, \mathrm{C})$ and YN (B,D) sites (see Fig. 1) from February 2005 to December 2006. FPOM: fine POM fraction $<20 \mu m_{i}$ CPOM: coarse POM fraction of 20 to $180 \mu \mathrm{m}_{i} \mathrm{CV}$ : coefficient of variation

\section{Seasonal growth patterns of suspension feeders}

After the spat were taken to the culture system of the farm in late winter and early spring, seasonal patterns in shell and tunic growth were very similar for both suspension feeders at the coculture (Goseong) site (see Fig. 3). The shell and tunic growth of Halocynthia roretzi and Crassostrea gigas started from spat deployment in February to March, and continued until harvesting in winter. In contrast, their condition showed a clear seasonal pattern that was very similar for both species (Fig. 4). Relatively high values of the condition index at the beginning of the study (winter to spring) were followed by a progressive decline throughout the summer to autumn period to minimum levels in September to October. A subsequent rapid recovery in condition occurred in November in both years, after
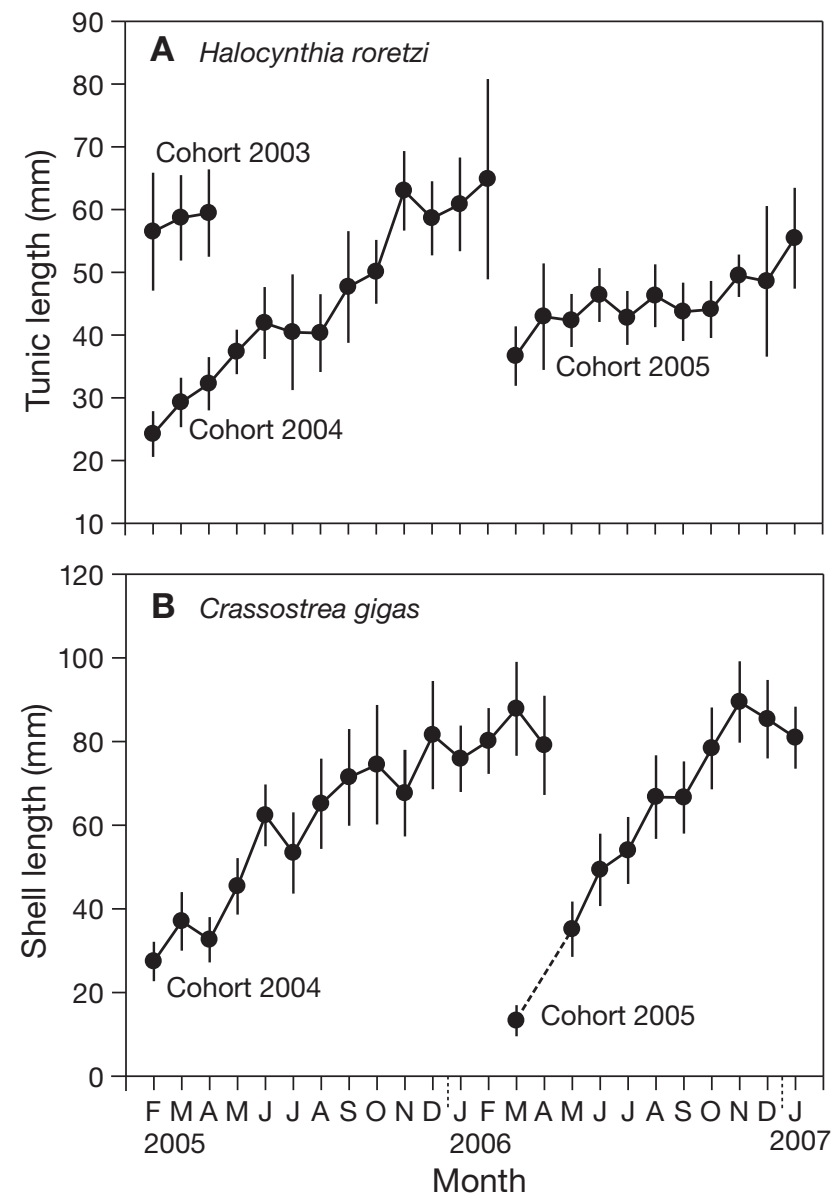

Fig. 3. Halocynthia roretzi and Crassostrea gigas. Seasonal growth patterns in: (A) sea squirt tunic and (B) oyster shell after the larva collectors were attached at Site C (see Fig. 1).

Dashed line: no data

which the condition index reached maximum levels in late winter (February to March) during the main harvesting period.

\section{$\delta^{13} \mathrm{C}$ and $\delta^{15} \mathrm{~N}$ values of the suspension feeders}

The $\delta^{13} \mathrm{C}$ and $\delta^{15} \mathrm{~N}$ values of the sea squirts and oysters showed significant temporal variations (Fig. 5; 1-way ANOVA, $\mathrm{p}<0.001$ for all 5 cases of both elements). Similar to the isotopic values of the POM, the $\delta^{13} \mathrm{C}$ values of the suspension feeders was less variable (CV range $=$ 3.2 to 6.0 ) than the $\delta^{15} \mathrm{~N}$ values over the sampling period ( $\mathrm{CV}$ range $=6.1$ to 12.7 ). On the other hand, while the coand monocultured sea squirts were less variable $(\mathrm{CV}=$ 3.5 and 3.4, respectively) than the cocultured oysters $(\mathrm{CV}=6.0)$ in the $\delta^{13} \mathrm{C}$ values, the former were more variable $(\mathrm{CV}=8.7$ and 12.7 , respectively) than the latter group $(\mathrm{CV}=7.3)$ in the $\delta^{15} \mathrm{~N}$ values over the sampling period. Along with the low variability in the $\delta^{13} \mathrm{C}$ values 

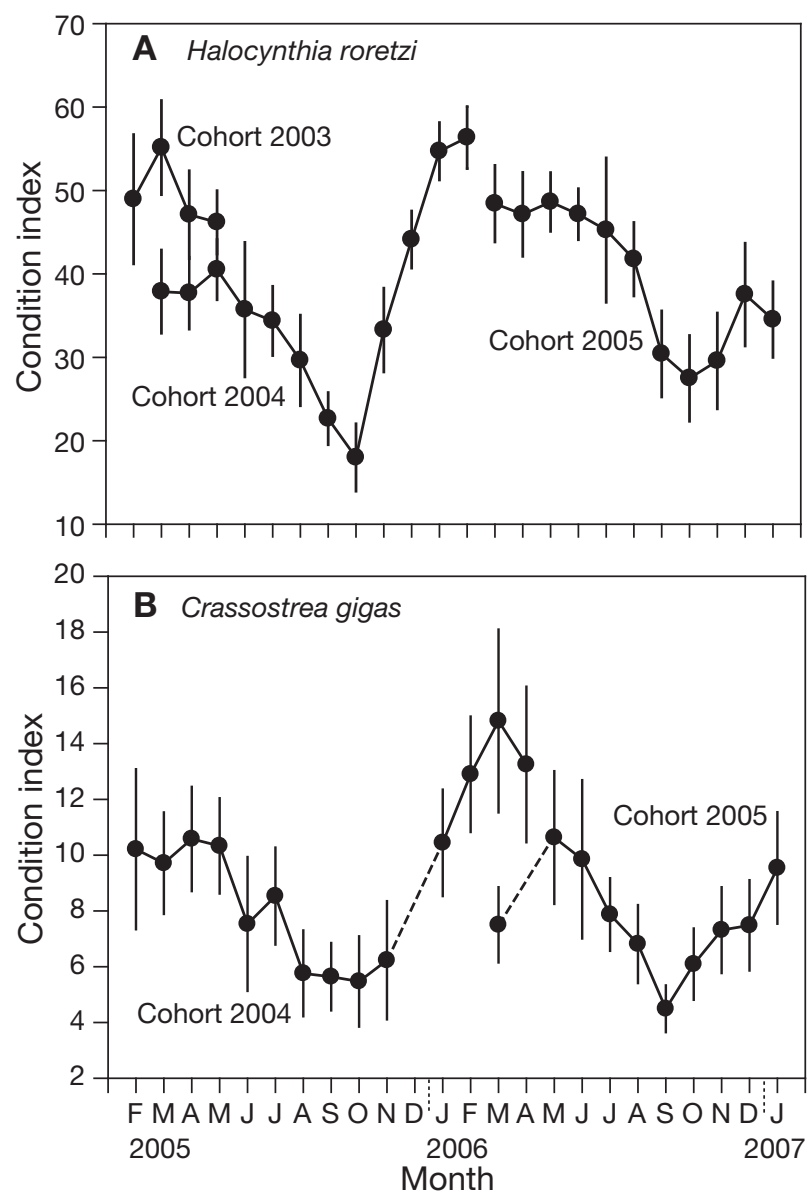

Fig. 4. Halocynthia roretzi and Crassostrea gigas. Seasonal variations in condition index [(dry tissue weight/dry tunic or shell weight) $\times 100$ ] of: $($ A) sea squirt and (B) oyster after the larva collectors were attached at Site C (see Fig. 1). Dashed lines: no data
The $\delta^{13} \mathrm{C}$ and $\delta^{15} \mathrm{~N}$ values of the cocultured sea squirts were consistently lower (range $=-21.6$ to $-19.4 \%$ ond 8.0 to $10.9 \%$, respectively) than those of the cocultured oysters (range $=-20.2$ to $-16.5 \%$ and 10.3 to $13.6 \%$, respectively) over the sampling period (Fig. 5). The mean differences between the 2 groups were $2.1 \pm 0.9 \%$ and $2.4 \pm 0.8 \%$, respectively (paired $t$-test, $\mathrm{p}=<0.001$ for both groups; Table 3 ). While the $\delta^{13} \mathrm{C}$ values of the cocultured sea squirts were slightly lower (mean difference $=$ $1.3 \pm 0.6 \%$ ) than those of the monocultured sea squirts (range $=-20.5$ to $-18.1 \%$ ), the $\delta^{15} \mathrm{~N}$ values showed no significant difference between both groups (range of the latter group $=6.9$ to $12.2 \%$, paired $t$-test, $\mathrm{p}=0.492$ ) Again, the cocultured sea squirts exhibited much lower $\delta^{13} \mathrm{C}$ values than those grown in nature (range $=-18.8$ to $-16.6 \%$ ) and monocultured oysters (range $=-18.7$ to $-16.5 \%$ ), with mean differences of $2.2 \pm 0.8 \%$ ond $2.6 \pm$ $0.7 \%$, respectively. The $\delta^{13} \mathrm{C}$ values of the monocultured sea squirts tended to be between those of the other sea squirt and oyster groups, resulting in reduced mean differences between the monocultured sea squirts and wild sea squirts or oyster groups compared to those between cocultured sea squirts and these groups. No significant difference was found in the $\delta^{13} \mathrm{C}$ values between wild sea squirts and co- or monocultured oysters (paired $t$-test, $\mathrm{p}=0.558$ and 0.383 , respectively). While the mean differences in the $\delta^{13} \mathrm{C}$ values between the sea squirt and oyster groups decreased from cocultured through monocultured sea squirts to insignificance in wild sea squirts. The large differences in the $\delta^{15} \mathrm{~N}$ values between the sea squirts and oysters were consistent (Table 3 ). The mean differences in the $\delta^{15} \mathrm{~N}$ values between the sea squirt groups were much lower than those between the sea squirts and the oysters. of the co- and monocultured sea squirts, their $\delta^{13} \mathrm{C}$ values showed irregular seasonal fluctuation. In contrast, the $\delta^{13} \mathrm{C}$ values of the co- and monocultured oysters displayed a clear seasonality, decreasing during winter to spring, and then increasing to a maximum in the late summer to autumn (Tukey HSD test, $\mathrm{p}<0.05)$. The $\delta^{15} \mathrm{~N}$ values of the co- and monocultured sea squirts and oysters increased during the summer to autumn, and fell to a minimum in winter (Tukey HSD test, $\mathrm{p}<0.05)$. From Spearman's rank correlation analyses (Table 2), similar seasonal trends in the variation in the $\delta^{13} \mathrm{C}$ values between species, or between sites for the same species, were found in a few cases ( 4 out of 10 correlations), but in most cases of the $\delta^{15} \mathrm{~N}$ values (8 out of 10 correlations).
Table 2. Halocynthia roretzi, Crassostrea gigas. Spearman's rank correlation analyses ( $\rho$ ) on the $\delta^{13} \mathrm{C}$ and $\delta^{15} \mathrm{~N}$ values between species, or between sampling sites for the same species

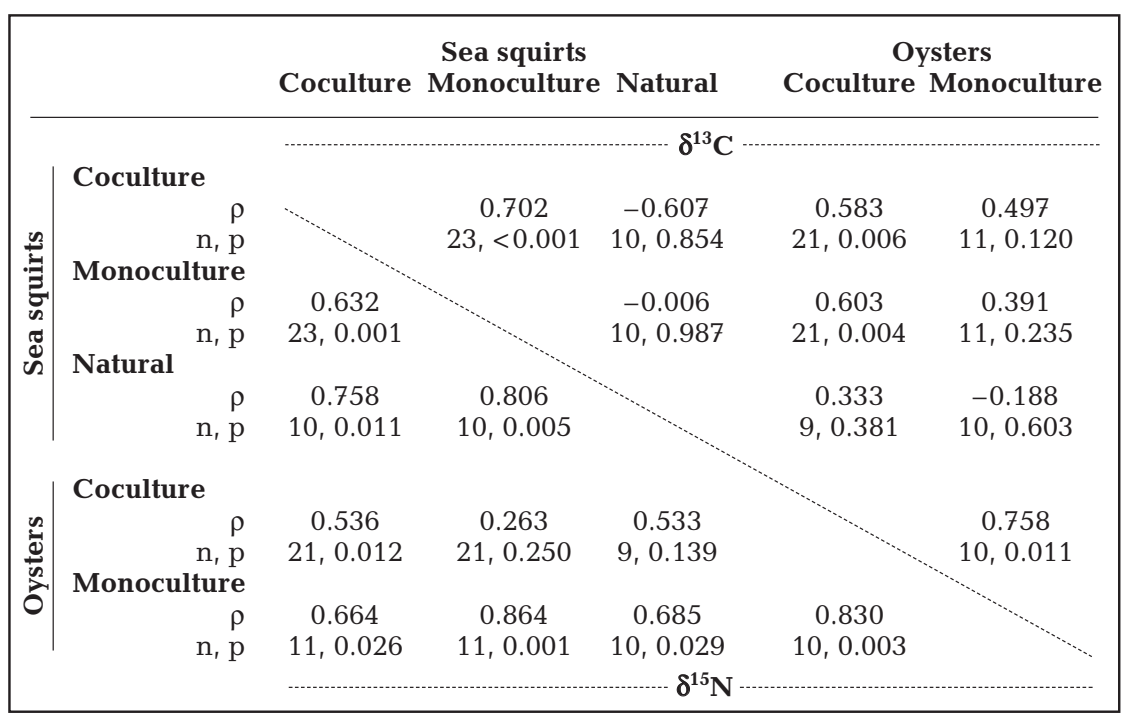



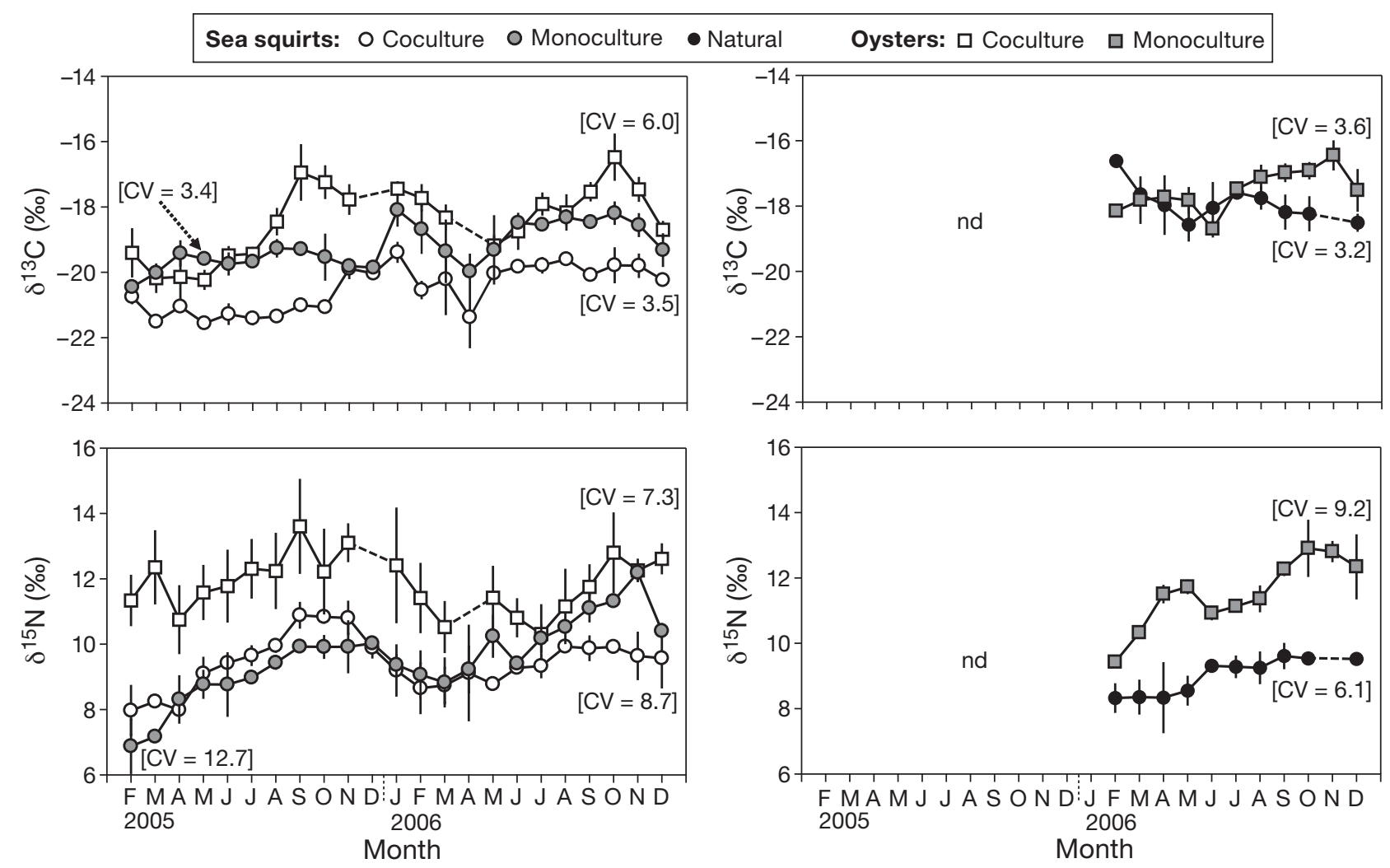

Fig. 5. Halocynthia roretzi and Crassostrea gigas. Monthly mean $( \pm 1 \mathrm{SD}) \delta^{13} \mathrm{C}$ and $\delta^{15} \mathrm{~N}$ values. Cocultured oysters and sea squirts, monocultured sea squirts from February 2005 to December 2006; natural sea squirts and monocultured oysters from February to December 2006; CV: coefficient of variation; nd: not determined

Table 3. Halocynthia roretzi and Crassostrea gigas. Results of paired $t$-test on the $\delta^{13} \mathrm{C}$ and $\delta^{15} \mathrm{~N}$ values between species, or between sampling sites for the same species

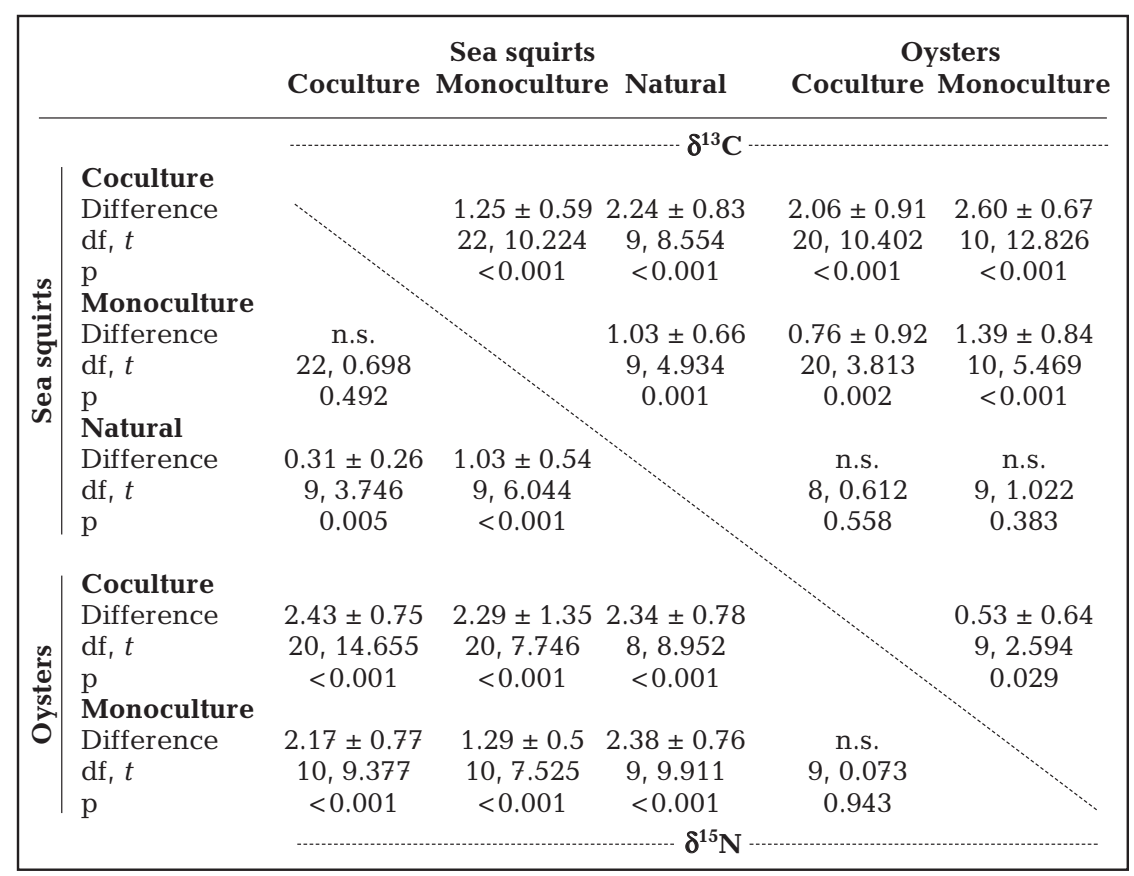

\section{DISCUSSION}

\section{Isotopic variations in size-fractionated marine particles}

The isotopic variability of the suspended POM observed in the present study was mainly due to differences between size classes, i.e. the CPOM and FPOM rather than between sites. The $\delta^{13} \mathrm{C}$ and $\delta^{15} \mathrm{~N}$ values of the FPOM (size fraction $<20 \mu \mathrm{m}$ ) were consistently lower by mean differences of 2.8 and $2.1 \%$, respectively, than those of the CPOM (size fraction $>20 \mu \mathrm{m}$ ). Such isotopic variations across the suspended POM size classes have been established in marine particles (Gearing et al. 1984, Minagawa \& Wada 1986, Goering et al. 1990, Rau et al. 1990, Kopczyńska et al. 1995, Kukert \& Riebesell 1998, Rolff 2000, Sato et al. 2006). Although researchers cannot completely explain the isotopic vari- 
ability, these previous studies have shown that POM size-dependent isotopic variations are likely to be due to the different taxonomic composition in each size class. For example, the $\delta^{13} \mathrm{C}$ values of the diatomdominated CPOM is generally higher than that of the nanoplankton-dominated, e.g. nanoflagellates, FPOM (Gearing et al. 1984, Goering et al. 1990, Rolff 2000). The presence of pico-size bacteria or prymnesiophytes can be also attributed to the lowered $\delta^{13} \mathrm{C}$ values of the FPOM (Bishop et al. 1977, Rau et al. 1990). Sato et al. (2006) speculated that the lower $\delta^{13} \mathrm{C}$ values of the FPOM than those of the CPOM may be related to taxonomic (or cell-size-specific) differences in carbon isotopic discrimination during photosynthesis. Similar observations were obtained for differences in the $\delta^{15} \mathrm{~N}$ values, showing a lower value in the smaller size class of the POM compared to larger counterparts (Wada et al. 1987, Altabet 1988, Rau et al. 1990, Sato et al. 2006). In particular, the $\delta^{15} \mathrm{~N}$ values of isolated blue-green alga were 2 to $4 \%$ lower than those of a towed plankton mixture using a phytoplankton net $(95 \mu \mathrm{m})$ in the East China Sea adjacent to the study area (Minagawa \& Wada 1986). Rau et al. (1990) found that nanoflagellates, which are important consumers of bacteria, dominated the microbial biomass at a Mediterranean site, and their $\delta^{15} \mathrm{~N}$ value was lower than that of POM $>20 \mu \mathrm{m}$. Thus $\mathrm{N}$ isotopic fractionation within the microbial food web may be different from that (3 to $5 \%$ fractionation per trophic level) of higher metazoan organisms. In addition, the possible existence of microzooplankton would partly explain the higher $\delta^{15} \mathrm{~N}$ values in the CPOM fraction.
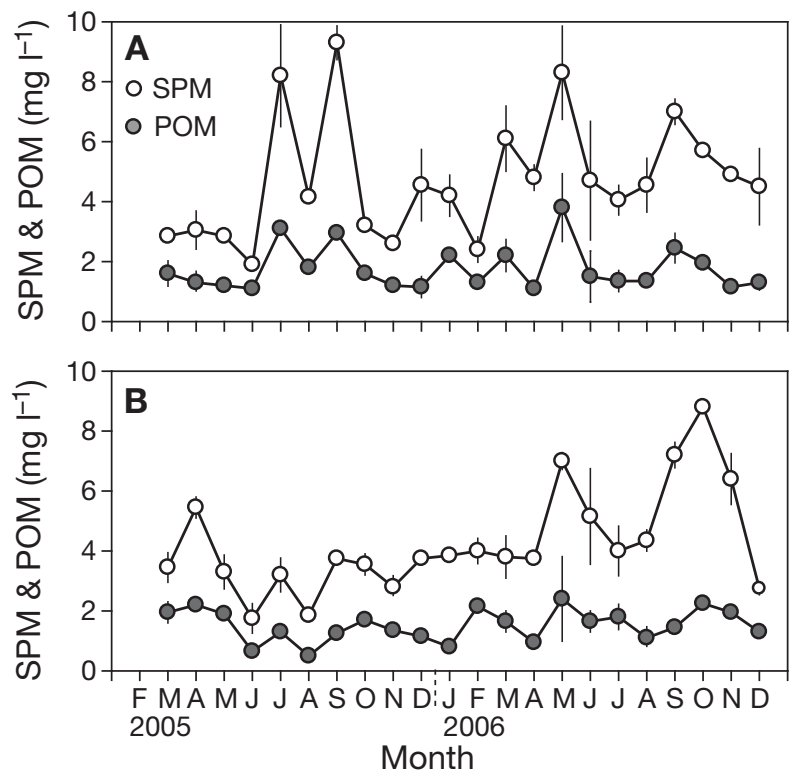

Terrestrial/marine organic matter mixing can explain the observed isotopic variation (e.g. Rau et al. 1990, Sato et al. 2006). However, the atomic $\mathrm{C} / \mathrm{N}$ ratios of the suspended POM in coastal waters adjacent to our sampling sites were typical of marine-origin materials (range $=3.7$ to 10.2 , mean $=7.7 \pm 1.3$ in the present study, versus 4.3 to 9.6 by Kang et al. 1999), which reject this hypothesis. Indeed, most of the $\delta^{13} \mathrm{C}$ values of the suspended POM in the present study fall within the range of values found for marine particulates (e.g. Fry \& Sherr 1984), and some high values (around $-15 \%$ ) in the CPOM are commonly found during the spring to summer diatom blooms in coastal waters (Masan Bay) adjacent to the study area (Kim et al. 1994). The seasonal distribution of seston concentrations and the seston composition at the studied sites indicated that these sites can be characterized as an open bay or an oceanic system. The seston concentrations ranged from 1.75 to $8.80 \mathrm{mg} \mathrm{l}^{-1}$ and from 1.90 to $9.30 \mathrm{mg} \mathrm{l}^{-1}$ at Sites GD and YN, respectively (Fig. 6). These values were lower than those for estuarine or inner bay systems (cf. Navarro et al. 1993, Danovaro \& Fabiano 1997, and also references therein). POM concentrations at the 2 sites were from 0.50 to $2.40 \mathrm{mg} \mathrm{l}^{-1}$ and 1.10 to $3.80 \mathrm{mg} \mathrm{l}^{-1}$, respectively, representing high organic fraction between 20 and $60 \%$ of the total seston. No clear seasonality in either the seston or POM concentrations was found, indicating no significant seston load by riverine discharge. In addition to the low $\mathrm{C} / \mathrm{N}$ ratios of the seston, low POC/chl a ratios $(<200$; authors' unpubl. data) found in the present study suggested the existence of a high amount of living material contained in the seston at the studied sites.
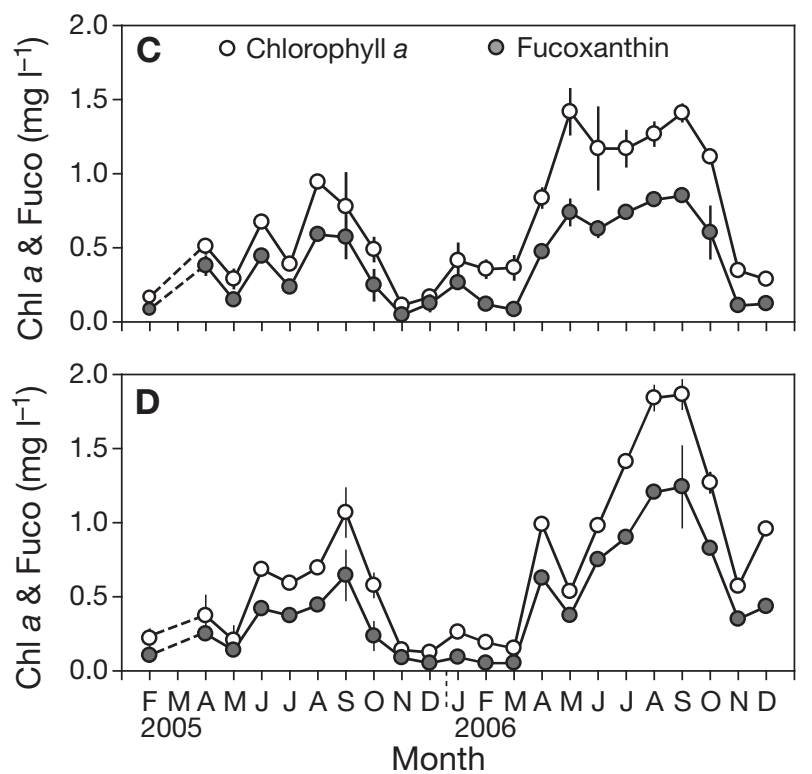

Fig. 6. Seasonal variations of suspended particulate matter (SPM), particulate organic matter (POM), chlorophyll a (Chl a) and fucoxanthin (Fuco, marker pigment for diatoms) in the water column at the GD $(A, C)$ and YN (B,D) sites (see Fig. 1) from February 2005 to December 2006 
A seasonally different variability in the $\delta^{13} \mathrm{C}$ and $\delta^{15} \mathrm{~N}$ values between the size classes of the POM was also apparent in the present study (Table 1, Fig. 2). Such seasonal variations have been studied in relation to internal isotope variability of the autochthonous producers in various coastal waters (Rau et al. 1990, Sato et al. 2006). The $\delta^{13} \mathrm{C}$ values of the CPOM were more variable than those of the FPOM over the sampling period, showing higher $\delta^{13} \mathrm{C}$ values in the CPOM in the summer or summer to early fall, when the water temperature was high. The phytoplankton composition of the southern coastal waters of Korea is characterized by a high instability (Kim et al. 2004). High $\delta^{13} \mathrm{C}$ values in the CPOM occurred when the chl a concentration was high. During that time, high fucoxanthin concentrations were detected, indicating a high contribution of diatoms to the phytoplankton biomass (Fig. 6). The $\delta^{13} \mathrm{C}$ values of phytoplankton are known to be dependent on growth rate, dissolved inorganic carbon dynamics, and taxonomic group (Cifuentes et al. 1988, Fry 1996, Kukert \& Riebesell 1998). Many diatoms are large, and their high $\delta^{13} \mathrm{C}$ values could result from higher growth rates, larger cell sizes, and carbon content; thereby, they would have a higher carbon demand compared to other taxonomic groups (Laws et al. 1995, Kukert \& Riebesell 1998). High temperatures in summer could decrease the $p \mathrm{CO}_{2}$ value, and isotopic discrimination between $\mathrm{HCO}_{3}^{-}$and $\mathrm{CO}_{2}$ (aq) (Wong \& Sackett 1978, Fontugne \& Duplessy 1981). Furthermore, a high growth rate, i.e. increased $\mathrm{CO}_{2}$ consumption, during the spring to summer phytoplankton bloom can lead to $\mathrm{CO}_{2}$ limitation in the water column and a smaller isotope discrimination. Similar to results found in the Delaware estuary (Cifuentes et al. 1988), these effects resulted in very high $\delta^{13} \mathrm{C}$ values of -9.2 to $-15.4 \%$ during a plankton bloom in coastal waters (Masan Bay) adjacent to the study area (Kim et al. 1994).

In contrast to the $\delta^{13} \mathrm{C}$ values, the $\delta^{15} \mathrm{~N}$ values of the CPOM were less variable than those of the FPOM, and the $\delta^{15} \mathrm{~N}$ values of the FPOM peaked in the summer to early fall of 2005. A higher seasonal variation of the $\delta^{15} \mathrm{~N}$ values in the FPOM than those in the CPOM has also been observed in other coastal waters (Rau et al. 1990, Sato et al. 2006). Nitrogen isotope discrimination of diatoms tends to decrease with growth rate, but not in other species (Montoya \& McCarthy 1995). As supported by an inverse relationship between $\mathrm{NO}_{3}^{-}$(or $\mathrm{NH}_{4}{ }^{+}$) ion concentrations and the $\delta^{15} \mathrm{~N}$ values of the POM, the $\delta^{15} \mathrm{~N}$ values of phytoplankton should be affected by differences in the availability of $\mathrm{NO}_{3}{ }^{-}$or $\mathrm{NH}_{4}{ }^{+}$ions, supporting phytoplankton production (Wada \& Hattori 1976, Benner et al. 1997, Sato et al. 2006). In fact, high sestonic $\delta^{15} \mathrm{~N}$ values during the course of algal growth can result from the assimilation of a nitrogen pool enriched in ${ }^{15} \mathrm{~N}$ because of previous fractionation by phytoplankton (Cifuentes et al. 1988, Goering et al. 1990). However, although the concentrations of dissolved inorganic nitrogen (DIN) slightly decreased in the upper layer during the summer stratified season in the present study, the concentrations still remained at a high level of 1 to $4 \mu \mathrm{M}$ (authors' unpubl. data). The atomic $\mathrm{C} / \mathrm{N}$ ratio of the suspended POM ranged from 5.4 to 6.8 during the spring to summer phytoplankton bloom in the present study (authors' unpubl. data). This $\mathrm{C} / \mathrm{N}$ range is typical of marine phytoplankton, implying that there was no limitation of nitrogen for phytoplankton growth. Indeed, during the summer season of heavy rainfall in the study area, the addition of excessive nitrogen via streams into the stratified coastal waters greatly proliferated the phytoplankton (mainly diatoms; see Kang et al. 1999). Along with a positive correlation between the $\delta^{15} \mathrm{~N}$ values of the POM and water temperature, a stronger temperature effect on the $\delta^{15} \mathrm{~N}$ values of the CPOM (compared to those of the FPOM) has also been reported (Goering et al. 1990, Sato et al. 2006). However, the temperature-dependent variation in the $\delta^{15} \mathrm{~N}$ values of the CPOM was unclear, and a greater seasonal variability was observed in the $\delta^{15} \mathrm{~N}$ values of the FPOM in the present study (Fig. 2). As a result, the large variability in taxonomy of the microbial community and the different physiological responses of the pico- and nano-size plankton from micro-size plankton were most likely responsible for the pronounced variations in the $\delta^{15} \mathrm{~N}$ values of the FPOM, as previously suggested (Rau et al. 1990, Sato et al. 2006).

\section{Size-dependent food partitioning between cocul- tured sea squirts and oysters}

A consistent discrepancy in the $\delta^{13} \mathrm{C}$ and $\delta^{15} \mathrm{~N}$ values between cocultured sea squirts Halocynthia roretzi and oysters Crassostrea gigas indicates that these 2 suspension-feeding species feed in different proportions on the organic constituents of suspended particulate matter. This explanation seems reasonable because of the seasonal trends in their isotopic signatures. While the seasonality of the $\delta^{13} \mathrm{C}$ values in cocultured oysters was similar to those of the CPOM, the cocultured sea squirts had a comparable seasonality of the $\delta^{15} \mathrm{~N}$ values to the FPOM. Accordingly, a seasonal trend in the $\delta^{13} \mathrm{C}$ values of a species was not necessarily consistent with its $\delta^{15} \mathrm{~N}$ values.

A dual isotope plot for the trophic components, including suspension feeders and size-fractionated particles, enabled us to elucidate the dietary sources assimilated by the consumers (Fig. 7). In stable isotope analysis, dietary sources assimilated by a consumer 
can be identified by assuming a trophic fractionation between the animal's tissue and its diet, which is generally accepted to be 0 to $1 \%$ for $\delta^{13} \mathrm{C}$ and 3 to $4 \%$ for $\delta^{15} \mathrm{~N}$ (Fry \& Sherr 1984, Minagawa \& Wada 1984). Recently, laboratory feeding experiments showed that the ${ }^{13} \mathrm{C}$ and ${ }^{15} \mathrm{~N}$ diet-tissue fractionations of Crassostrea gigas, were outside the abovementioned range (Dubois et al. 2007a, Yokoyama et al. 2008). However, Yokoyama et al. (2008) suggested that the ${ }^{13} \mathrm{C}$ fractionation for the whole soft body of the oysters is $\leq 1.0 \%$, and the actual $\delta^{15} \mathrm{~N}$ fractionation of the oysters in the field is smaller than that obtained from the rearing experiment on a monospecific microalgal diet. Accordingly, we assumed the generally accepted trophic enrichments of $1 \%$ for $\delta^{13} \mathrm{C}$ and $3.5 \%$ or $\delta^{15} \mathrm{~N}$, respectively (e.g. Riera et al. 2002, Dubois et al. 2007b), and estimated the isotopic ranges of consumers assimilating a diet (indicated by the dashed line in Fig. 7). The results of the dual isotope plot confirmed the dietary switch between the cocultured suspension feeders.

The ranges of the $\delta^{13} \mathrm{C}$ and $\delta^{15} \mathrm{~N}$ values of the cocultured oysters ( -20.2 to $-16.5 \%$ and 10.3 to $13.6 \%$, respectively) suggest that the CPOM was their primary dietary component. This conclusion may be supported by the seasonal variations in the isotopic composition

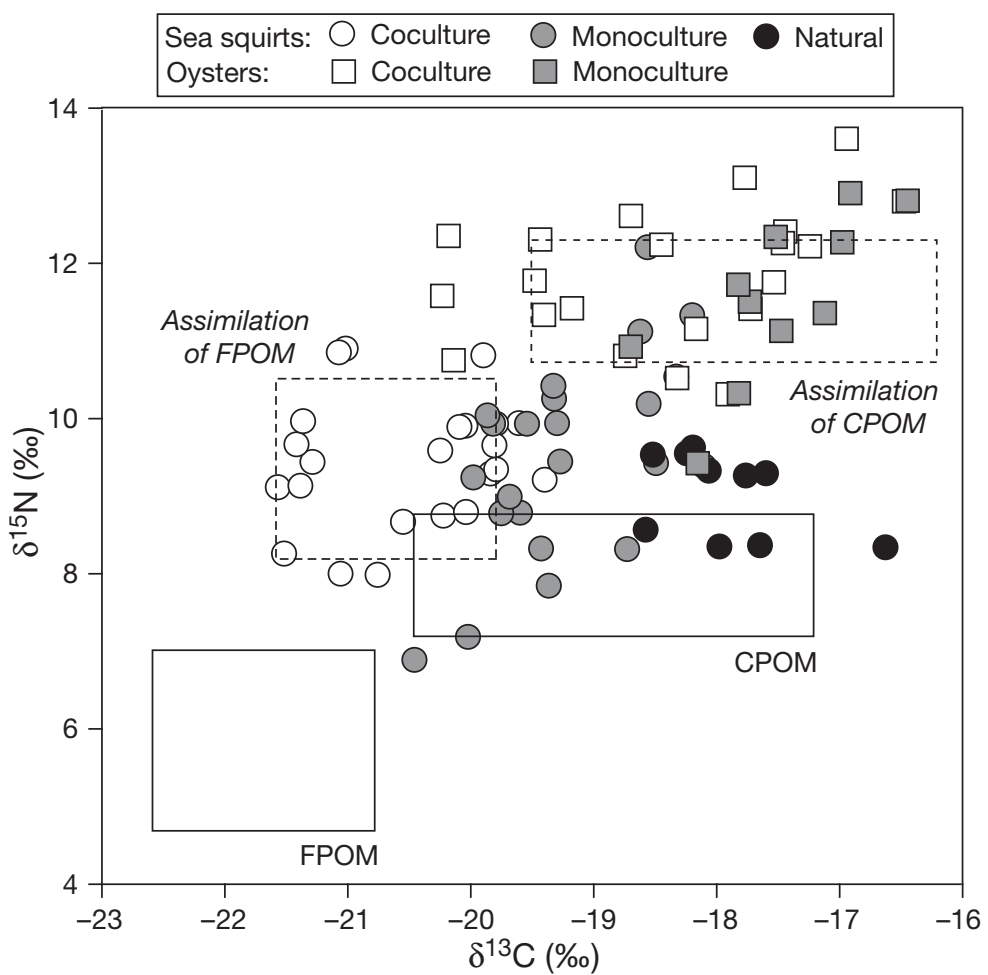

Fig. 7. Dual plot of $\delta^{13} \mathrm{C}$ and $\delta^{15} \mathrm{~N}$ values for suspension feeders and sizefractionated suspended particulate organic matter (POM). Expected $\delta^{13} \mathrm{C}$ and $\delta^{15} \mathrm{~N}$ ranges (as indicated by the dashed line) of consumers assimilating the fine and coarse POM (FPOM, CPOM) fractions were calculated by assuming trophic enrichments of 0.4 to $2.0 \%$ for $\delta^{13} \mathrm{C}$ and 2.2 to $5.0 \%$ for $\delta^{15} \mathrm{~N}$, respectively of cocultured oysters. Seasonal peaks in the $\delta^{13} \mathrm{C}$ values of cocultured oysters occurred in the summer or summer to early fall, when the CPOM was most ${ }^{13} \mathrm{C}$ enriched by a seasonal diatom bloom. Consistent seasonal ${ }^{13} \mathrm{C}$ enrichment was also found for the monocultured oysters. Therefore, there was a slight difference in the $\delta^{13} \mathrm{C}$ values between co- and monocultured oysters, but by only a mean of $0.5 \pm 0.64 \%$, and no significant difference in the $\delta^{15} \mathrm{~N}$ values was found (Table 3 ). This result suggests that both co- and monocultured oysters rely largely on a CPOM diet source. In contrast, no pronounced ${ }^{13} \mathrm{C}$ enrichment appeared in the cocultured sea squirts during that time. A ciliary filterfeeding mechanism (termed cirri trapping) gives bivalves the ability to sort particles before ingestion; thus, Pacific oysters do not retain the smallest cells in the water column (Courties et al. 1994, Riisgård \& Larsen 2000). Their preingestive selection to regulate the ingestion of particles by production of pseudofeces can also discriminate inorganic and organic particles, and different species of microalgae (Shumway et al. 1985). Such a qualitative selection capability can lead to preferential absorption and ingestion of microalgae by Pacific oysters (Shumway et al. 1985, Barillé et al. 1997, Cognie et al. 2001). As a result, a similar seasonality in the $\delta^{13} \mathrm{C}$ and values between oysters and the CPOM, and the range of $\delta^{13} \mathrm{C}$ and $\delta^{15} \mathrm{~N}$ values of oysters in this study, indicates the qualitative selection of microalgae (particularly diatoms) by oysters (cf. Decottignies et al. 2007, Marín Leal et al. 2008). On the other hand, oysters had more ${ }^{13} \mathrm{C}$-depleted values relative to the remainder of the year, in early spring prior to the microalgal bloom, coinciding with that of the CPOM. While the seasonal difference in the $\delta^{13} \mathrm{C}$ values between the 2 species during that time was reduced, the $\delta^{15} \mathrm{~N}$ values of oysters was still higher than that of sea squirts, reflecting the difference in $\delta^{15} \mathrm{~N}$ values between the size fractions of the POM. Accordingly, this result also suggests the oysters' ability to selectively ingest CPOM by size-dependent sorting.

The range of $\delta^{13} \mathrm{C}$ and $\delta^{15} \mathrm{~N}$ values of the cocultured sea squirts ( -21.6 to $-19.4 \%$ and 8.0 to $10.9 \%$, respectively) were, on average, depleted 2.1 and $2.4 \%$, respectively, compared to the $\delta^{13} \mathrm{C}$ and $\delta^{15} \mathrm{~N}$ values of oysters, implying an increased assimilation of the FPOM. Seasonal trends in the $\delta^{13} \mathrm{C}$ and $\delta^{15} \mathrm{~N}$ values of cocultured sea squirts tended to parallel those of the FPOM. Although cocultured oysters had higher $\delta^{13} \mathrm{C}$ values just after the summer or autumn diatom 
blooms, and no comparable ${ }^{13} \mathrm{C}$ enrichment was found in cocultured sea squirt tissue at the same time. Rather, the $\delta^{15} \mathrm{~N}$ values of cocultured sea squirts were greatly elevated, and coincident with the FPOM during that time. Effective use of the FPOM (pico- and nano-size plankton) by the cocultured sea squirts may be explained by their particle capture mechanism, characterized by net trapping (Riisgård \& Larsen 2000). Ascidians deploy filter nets arranged in rectangular meshes of very fine filaments on the inner surface of the branchial basket (Flood \& Fiala-Médioni 1981). The mucus net of ascidians can retain complete particles down to a size of 2 to $3 \mu \mathrm{m}$ (see Riisgård \& Larsen 2000, Bone et al. 2003). An experimental study on a similar ascidian species, Halocynthia pyriformis, demonstrated that with increasing sediment concentration the retention of small particles (2 to $5 \mu \mathrm{m}$ ) increased, while retention of larger particles (5 to $15 \mu \mathrm{m}$ ) decreased (Armsworthy et al. 2001).

On the other hand, while the $\delta^{13} \mathrm{C}$ values of the sea squirts were different between co- and monocultured sites and wild habitats, there was no great difference in the $\delta^{13} \mathrm{C}$ values between co- and monocultured oysters. This result suggests that unlike oysters, sea squirts lack particle-sorting mechanisms, and their indiscriminate feeding habits may lead to their dietary plasticity, depending on the availability of food resources (Coma et al. 2001, Petersen 2007). The higher $\delta^{13} \mathrm{C}$ and $\delta^{15} \mathrm{~N}$ values of monocultured sea squirts during the summer to autumn of 2006, when the microalgal biomass peaked, compared to the rest of the study period, most likely reflect the increased use of diatom-derived microalgae. Further, the higher $\delta^{13} \mathrm{C}$ values and lower $\delta^{15} \mathrm{~N}$ values of the wild sea squirts compared to co- and monocultured sea squirts indicates the assimilation of the specially ${ }^{13} \mathrm{C}$-enriched and ${ }^{15} \mathrm{~N}$-depleted fractions in their diets. Considering that the habitats of the wild sea squirts are characterized by hard substrates colonized by macroalgae, the most probable candidates accountable for their isotope composition are macroalgal detritus, which have, on average, $-17.2 \pm 3.3 \%$ and $3.2 \pm 1.3 \%$ or the $\delta^{13} \mathrm{C}$ and $\delta^{15} \mathrm{~N}$ values, respectively (Kang et al. 2008).

The trophic relationships between cultivated oysters and co-occurring suspension feeders, slippersnails, or ascidians have also been exemplified in intertidal shellfish ecosystems on the French coast (Riera et al. 2002, Decottignies et al. 2007, Dubois et al. 2007b). These authors examined the dietary contributions of various potential food sources, including POM, benthic diatoms, macroalgae, C3 or C4 angiosperms, and terrestrial materials, to the animal tissues, using spatial or temporal variability in isotopic composition. They concluded that food resource partitioning due to a fundamental difference in feeding biology and the trophic plasticity of the co-occurring suspension feeders can limit interspecific competition for food. For example, Dubois et al. (2007b) found that, while oysters exhibited large spatial variations in isotopic signatures, ascidians had consistent isotopic signatures, showing the capability for greater trophic plasticity in oysters than in ascidians. These authors concluded that intraspecific variability in relative contributions of organic matter sources (i.e. terrestrial organic matter, microphytobenthos, Ulva, and marine particulate organic matter) according to the feeding biology and trophic plasticity of co-occurring suspension feeders can result in food resource partitioning in the intertidal ecosystem. Spatial variability in isotopic signatures of oysters and sea squirts found in the present study seems to be contradictory to the conclusion of Dubois et al. (2007b). However, considering the common trophic plasticity in consumers according to the availability of food items, such variability between systems seems to be reasonable. Our suspended culture system is in an open coastal area where the trophic base is largely dependent on water column production, and probably lacks benthic or terrestrial sources. In this system, cocultured suspension feeders, sea squirts, and Pacific oysters seem to partition their food resources in slightly different ways. Our isotopic data suggest that the 2 cocultured suspension feeders can exploit resources from the different size fractions of the entire POM pool. Laboratory feeding experiments for several suspension feeders from kelp beds have clearly shown a difference in concentrations of carbon and nitrogen ingested from different size fractions of particulate material between bivalves and ascidians (Stuart \& Klump 1984).

\section{Implications for the sustainability of aquaculture activity}

The 2 suspension feeders initiate gametogenesis simultaneously with condition recovery in late autumn (Kang et al. 2000 for oysters, authors' unpubl. data for sea squirts). Although the spawning of sea squirts occurs in winter (mainly at the end of December), weight loss following spawning was undetectable using our monthly sampling scheme. In contrast, the spawning of oysters occurs in late spring to summer and accompanies a distinct loss in tissue weight. A progressive decline in tissue weight of the sea squirts also occurs throughout the summer to autumn period. Then, despite different reproductive strategies, their tissue growth appears to be completed from late autumn to spring, indicating temporal coupling in tissue growth. Adequate exploitation of food resources to meet high energy costs required during the critical period for growth and gametogenesis will determine 
growth and production of these cultured stocks. Mass mortality of the monocultured sea squirts was encountered during the time of main growth and gametogenesis (winter to early spring). Ascidian mortality does not occur under cocultures of ascidians and oysters during the high energy-demand period. As previously shown for oysters in the neighboring culture system (Kang et al. 2000), a stocking density of sea squirts that exceeds the carrying capacity for the monoculturing ecosystem is likely to lead to food limitation, and thereby a decline in their growth rate and survival. If the reduced mortality under the coculture condition resulted from a mitigation of food limitation according to the trophic capacity of the system, then interspecific competition for food can be expected to be minimized. Our isotopic evidence confirms that a fundamental difference in the food particle capture mechanism between suspension-feeding sea squirts and oysters may reduce interspecific competition by food resource partitioning based on particle size. The coculture activity of ascidians and oysters retains high individual numbers and biomasses of suspension-feeding animals. However, the abovementioned evidence suggests that the exploitation of different food resources between the 2 suspension feeders may play an important role in reducing the nutritionally stressful effects of stocking density on growth and survival.

The present study demonstrates size-related patterns in food resource exploitation, presumably depending on the particle capture mechanism of cocultured suspension feeders. Further important ecological questions still remain: 'To what degree do suspension feeders actually retain each particle size fraction?', and 'To what degree does each size class support their $\mathrm{C}$ and $\mathrm{N}$ requirements?' Notwithstanding, this isotopic approach, based on size-fractionated suspended POM and associated biota, was found to be a simpler and more useful way to better understand trophic relationships and the nature of $\mathrm{C}$ and $\mathrm{N}$ cycling in these types of pelagic food webs.

Acknowledgements. Funding for this project was provided by an MCP Research Grant, Tunicate Aquaculture Stabilization Study of the National Fisheries Research \& Development Institute (NFRDI) of Korea. This research was also supported, in part, by the STAR France-Korea collaboration project (2006-00656).

\section{LITERATURE CITED}

Altabet MA (1988) Variations in nitrogen isotopic composition between sinking and suspended particles: implications for nitrogen cycling and particle transformation in the open sea. Deep-Sea Res 29:1035-1039

Armsworthy SL, MacDonald BA, Ward JE (2001) Feeding activity, absorption efficiency and suspension feeding process in the ascidian, Halosynthia pyriformis (Stolido- branchia: Ascidiacea): response to variations in diet quantity and quality. J Exp Mar Biol Ecol 260:41-69

Asmus RM, Asmus H (1991) Mussel beds: limiting or promoting phytoplankton? J Exp Mar Biol Ecol 148:215-232

Baker SM, Levinton JS, Durdziel JP, Shumway SE (1998) Selective feeding and biodeposition by zebra mussels and their relation to changes in phytoplankton composition and seston load. J Shellfish Res 17:1207-1213

Barillé L, Prou J, Héral M, Razet D (1997) Effects of high natural seston concentrations on the feeding, selection, and absorption of the oyster Crassostera gigas (Thunberg). J Exp Mar Biol Ecol 212:149-172

Benner R, Biddanda B, Black B, McCarthy M (1997) Abundance, size distribution, and stable carbon and nitrogen isotopic compositions of marine organic matter isolated by tangential-flow ultrafiltration. Mar Chem 57:243-263

Bishop JKB, Edmond JM, Ketten DR, Bacon MP, Silker WB (1977) The chemistry, biology, and vertical flux of particulate matter from the upper $400 \mathrm{~m}$ of the equatorial Atlantic Ocean. Deep-Sea Res 24:511-548

Bone Q, Carré C, Chang P (2003) Tunicate feeding filters. J Mar Biol Assoc UK 83:907-919

Bunn SE, Loneragan NR, Kempster MA (1995) Effects of acid washing on stable isotope ratios of $\mathrm{C}$ and $\mathrm{N}$ in penaeid shrimp and seagrass: implication for food-web studies using multiple stable isotopes. Limnol Oceanogr 40:622-625

Carver CE, Chisholm A, Mallet AL (2003) Strategies to mitigate the impact of Ciona intestinalis (L.) biofouling on shellfish production. J Shellfish Res 22:621-631

Cayer D, MacNeil M, Bagnall AG (1999) Tunicate fouling in Nova Scotia aquaculture: a new development. J Shellfish Res 18:327 (abstract)

Cifuentes LA, Sharp JH, Fogel ML (1988) Stable carbon and nitrogen isotope biogeochemistry in the Delaware estuary. Limnol Oceanogr 33:1102-1115

$>$ Cloern JE (1982) Does the benthos control phytoplankton biomass in South San Francisco Bay? Mar Ecol Prog Ser 9: 191-202

> Cognie B, Barillé L, Rincé Y (2001) Selective feeding of the oyster Crassostera gigas fed on a natural microphytobenthos assemblage. Estuaries 24:126-131

Coma R, Ribes M, Gili JM, Hughes RN (2001) The ultimate opportunists: consumers of seston. Mar Ecol Prog Ser 219: 305-308

> Courties C, Vaquer A, Troussellier M, Lautier J and others (1994) Smallest eukaryotic organism. Nature 370:255

> Danovaro R, Fabiano M (1997) Seasonal changes in quality and quantity of food available for benthic suspensionfeeders in the Golfo Marconi (north-western Mediterranean). Estuar Coast Shelf Sci 44:723-736

Decottignies P, Beninger PG, Rincé Y, Riera P (2007) Trophic intractions between two introduced suspension-feeders, Crepidula fornicata and Crassostrea gigas, are influenced by seasonal effects and qualitative selection capacity. J Exp Mar Biol Ecol 342:231-241

- Dubois S, Jean-Louis B, Bertrand B, Lefebvre S (2007a) Isotope trophic-step fractionation of suspension-feeding species: implications for food partitioning in coastal ecosystems. J Exp Mar Biol Ecol 351:121-128

Dubois S, Orvain F, Marin-Léal JC, Ropert M, Lefebvre S (2007b) Small-scale spatial variability of food partitioning between cultivated oysters and associated suspensionfeeding species, as revealed by stable isotopes. Mar Ecol Prog Ser 336:151-160

Flood PR, Fiala-Médioni A (1981) Ultrastructure and histochemistry of the food trapping mucous film in benthic filter-feeders (ascidians). Acta Zool 62:53-65 
Fontugne MR, Duplessy JC (1981) Organic carbon isotope fractionation by marine plankton in the temperature range -1 to $31^{\circ} \mathrm{C}$. Oceanol Acta 4:85-90

Fry B (1996) ${ }^{13} \mathrm{C} /{ }^{12} \mathrm{C}$ fractionation by marine diatoms. Mar Ecol Prog Ser 134:283-294

Fry B, Sherr EB (1984) $\delta^{13} \mathrm{C}$ measurements as indicators of carbon flow in marine and freshwater ecosystems. Contrib Mar Sci 27:13-47

Garen P, Robert S, Bougrier S (2004) Comparison of growth of mussel, Mytilus edulis, on longline, pole and bottom culture sites in the Pertuis Breton, France. Aquaculture 232:511-524

Gearing JN, Gearing PJ, Rundick DT, Requejo AG, Hutchins MJ (1984) Isotopic variability of organic carbon in a phytoplankton-based temperate estuary. Geochim Cosmochim Acta 48:1089-1098

Goering J, Alexander V, Haubenstock N (1990) Seasonal variability of stable carbon and nitrogen isotope ratios of organisms in a North Pacific bay. Estuar Coast Shelf Sci 30:239-260

Jarry V, Fiala M, Frisoni GF, Jacques G, Neveux J, Panouse M (1990) The spatial distribution of phytoplankton in a Mediterranean lagoon (Etang de Thau). Oceanol Acta 13: 503-512

Kang CK, Kim PJ, Lee WC, Lee PY (1999) Nutrients and phytoplankton blooms in the southern coastal waters of Korea. I. The elemental composition of $\mathrm{C}, \mathrm{N}$, and $\mathrm{P}$ in particulate matter in the coastal bay systems. J Korean Soc Oceanogr 34:86-94

Kang CK, Park MS, Lee PY, Choi WJ, Lee WC (2000) Seasonal variations in condition, reproductive activity, and biochemical composition of the Pacific oyster, Crassostrea gigas (Thunberg), in suspended culture in two coastal bays of Korea. J Shellfish Res 19:771-778

Kang CK, Choy EJ, Son Y, Lee JY, Kim JK, Kim Y, Lee KS (2008) Food web structure of a restored macroalgal bed in the eastern Korean peninsula determined by $\mathrm{C}$ and $\mathrm{N}$ stable isotope analyses. Mar Biol 153:1181-1198

Kim ES, Cho SR, Kang DJ, Hwang HM (1994) Stable carbon isotope ratios of particulate organic matters in Masan Bay. Ocean Res 16:29-34

Kim HG, Kang YS, Lee SG, Bae HM and others (2004) Harmful algal blooms in Korean coastal waters from 2002 to 2003. National Fisheries Research \& Development Institute, Pusan

Kopczyńska E, Goeyens L, Semeneh M, Dehairs F (1995) Phytoplankton composition and cell carbon distribution in Prydz Bay, Antarctica: relation to organic particulate matter and its $\delta^{13} \mathrm{C}$ values. J Plankton Res 17:685-707

Kukert H, Riebesell U (1998) Phytoplankton carbon isotope fractionation during a diatom spring bloom in a Norwegian fjord. Mar Ecol Prog Ser 173:127-137

Laws EA, Popp BN, Bidigare RR, Kennicutt MC, Macko SA (1995) Dependence of phytoplankton carbon isotopic composition on growth rate and $\left[\mathrm{CO}_{2}\right]_{\mathrm{aq}}$ : theoretical considerations and experimental results. Geochim Cosmochim Acta 59:1131-1138

Lesser MP, Shumway SE, Cucci T, Smith J (1992) Impact of fouling organisms on mussel rope culture: interspecific competition for food among suspension-feeding invertebrates. J Exp Mar Biol Ecol 165:91-102

- Marín Leal JC, Dubois S, Orvain F, Galois R and others (2008) Stable isotopes $\left(\delta^{13} \mathrm{C}, \delta^{15} \mathrm{~N}\right)$ and modeling as tools to estimate the trophic ecology of cultivated oysters in two contrasting environments. Mar Biol 153:673-688

> Minagawa M, Wada E (1984) Stepwise enrichment of ${ }^{15} \mathrm{~N}$ along food chains: further evidence and the relation be- tween ${ }^{15} \mathrm{~N}$ and animal age. Geochim Cosmochim Acta 48: $1135-1140$

Minagawa M, Wada E (1986) Nitrogen isotope ratios of red tide organisms in the East China Sea: a characterization of biological nitrogen fixation. Mar Chem 19:245-259

Montoya JP, McCarthy JJ (1995) Isotopic fractionation during nitrate uptake by phytoplankton grown in continuous culture. J Plankton Res 17:439-464

National Fisheries Research and Development Institute (2004) Korea-US aquaculture. Available at: www.lib.noaa.gov/ korea/main_species/sea_squirt.htm

> Navarro JM, Clasing E, Urrutia G, Asencio G, Stead R, Herrera C (1993) Biochemical composition and nutritive value of suspended particulate matter over a tidal flat of southern Chile. Estuar Coast Shelf Sci 37:59-73

Newell CR (1990) The effects of mussel (Mytilus edulis Linnaeus, 1758) position in seeded bottom patches on growth at subtidal lease sites in Maine. J Shellfish Res 9: $113-118$

> Parsons GJ, Dadwell MJ (1992) Effect of stocking density on growth, production and survival of the giant scallop, Placopecten magellanicus, held in intermediate suspension culture in Plassamaquoddy Bay, New Brunswick. Aquaculture 103:291-309

Petersen JK (2007) Ascidian suspension feeding. J Exp Mar Biol Ecol 342:127-137

> Petersen JK, Schou O, Thor P (1997) In situ growth of the ascidian Ciona intestinalis (L.) and the blue mussel Mytilus edulis in an eelgrass meadow. J Exp Mar Biol Ecol 218: $1-11$

Prins TC, Smaal AC, Dame RF (1997) A review of the feedbacks between bivalve grazing and ecosystem processes. Aquat Ecol 31:349-359

Raillard O, Ménesguen A (1994) An ecosystem box model for estimating the carrying capacity of a macrotidal shellfish system. Mar Ecol Prog Ser 115:117-130

- Rau GH, Teyssie JL, Rassoulzadegan F, Fowler SW (1990) ${ }^{13} \mathrm{C} /{ }^{12} \mathrm{C}$ and ${ }^{15} \mathrm{~N} /{ }^{14} \mathrm{~N}$ variations among size-fractionated marine particles: implications for their origin and trophic relationships. Mar Ecol Prog Ser 59:33-38

> Riera P, Stal LJ, Nieuwenhuize J (2002) $\delta^{13} \mathrm{C}$ versus $\delta^{15} \mathrm{~N}$ of cooccurring molluscs within a community dominated by Crassostrea gigas and Crepidula fornicata (Oosterschelde, The Netherlands). Mar Ecol Prog Ser 240:291-295

> Riisgård HU, Larsen PS (2000) Comparative ecophysiology of active zoobenthic filter feeding, essence of current knowledge. J Sea Res 44:169-193

Rodhouse PG, Roden CM, Barnell GM, Hensey MP, McMahon T, Ohway B, Ryan TH (1984) Food resource, gametogenesis and growth of Mytilus edulis on the shore and in suspended culture, Killary Harbour, Ireland. J Mar Biol Assoc UK 64:513-529

Rolff C (2000) Seasonal variation in $\delta^{13} \mathrm{C}$ and $\delta^{15} \mathrm{~N}$ of sizefractionated plankton at a coastal station in the northern Baltic proper. Mar Ecol Prog Ser 203:47-65

Sato T, Miyajima T, Ogawa H, Umezawa Y, Koike I (2006) Temporal variability of stable carbon and nitrogen isotopic composition of size-fractionated particulate organic matter in the hypertrophic Sumida River estuary of Tokyo Bay, Japan. Estuar Coast Shelf Sci 68:245-258

> Shumway SE, Cucci TL, Newell RC, Yentsch CM (1985) Particle selection, ingestion, and absorption in filter-feeding bivalves. J Exp Mar Biol Ecol 91:77-92

> Souchu P, Vaquer A, Collos Y, Landrein S, Deslous-Paoli JM, Bibent B (2001) Influence of shellfish farming activities on the biogeochemical composition of the water column in Thau lagoon. Mar Ecol Prog Ser 218:141-152 
Stuart V, Klump DW (1984) Evidence for food-resource partitioning by kelp-bed filter feeders. Mar Ecol Prog Ser 16: $27-37$

> Wada E, Hattori A (1976) Natural abundance of ${ }^{15} \mathrm{~N}$ in particulate organic matter in the North Pacific Ocean. Geochim Cosmochim Acta 40:249-251

$>$ Wada E, Minagawa M, Mizutani H, Hsuji T, Imaizumi R, Karasawa K (1987) Biogeochemical studies on the trans-

Submitted: May 23, 2008; Accepted: October 17, 2008 port of organic matter along the Otsuchi River watershed, Japan. Estuar Coast Shelf Sci 25:321-336

- Wong WW, Sackett WM (1978) Fractionation of stable carbon isotopes by marine phytoplankton. Geochim Cosmochim Acta 42:1809-1815

Yokoyama H, Ishihi Y, Yamamoto S (2008) Diet-tissue isotopic fractionation of the Pacific oyster Crassostrea gigas. Mar Ecol Prog Ser 358:173-179

Proofs received from author(s): March 14, 2009 